\title{
Synthesis, Optical Characterization, and Thermal Decomposition of Complexes Based on Biuret Ligand
}

\author{
Mei-Ling Wang, Guo-Qing Zhong, and Ling Chen \\ School of Material Science and Engineering, Southwest University of Science and Technology, Mianyang 621010, China \\ Correspondence should be addressed to Guo-Qing Zhong; zgq316@163.com
}

Received 28 October 2015; Accepted 9 February 2016

Academic Editor: Marek Samoc

Copyright (C) 2016 Mei-Ling Wang et al. This is an open access article distributed under the Creative Commons Attribution License, which permits unrestricted use, distribution, and reproduction in any medium, provided the original work is properly cited.

\begin{abstract}
Four complexes were synthesized in methanol solution using nickel acetate or nickel chloride, manganese acetate, manganese chloride, and biuret as raw materials. The complexes were characterized by elemental analyses, UV, FTIR, Raman spectra, Xray powder diffraction, and thermogravimetric analysis. The compositions of the complexes were $\left[\mathrm{Ni}(\mathrm{bi})_{2}\left(\mathrm{H}_{2} \mathrm{O}\right)_{2}\right](\mathrm{Ac})_{2} \cdot \mathrm{H}_{2} \mathrm{O}(\mathbf{1})$, $\left[\mathrm{Ni}(\mathrm{bi})_{2} \mathrm{Cl}_{2}\right](2),\left[\mathrm{Mn}(\mathrm{bi})_{2}(\mathrm{Ac})_{2}\right] \cdot 1.5 \mathrm{H}_{2} \mathrm{O}(3)$, and $\left[\mathrm{Mn}(\mathrm{bi})_{2} \mathrm{Cl}_{2}\right](4)\left(\mathrm{bi}=\mathrm{NH}_{2} \mathrm{CONHCONH}{ }_{2}\right)$, respectively. In the complexes, every metal ion was coordinated by oxygen atoms or chlorine ions and even both. The nickel and manganese ions were all hexacoordinated. The thermal decomposition processes of the complexes under air included the loss of water molecule, the pyrolysis of ligands, and the decomposition of inorganic salts, and the final residues were nickel oxide and manganese oxide, respectively.
\end{abstract}

\section{Introduction}

Biuret contains two acylamino groups and one imino group, the structure of which determines its value on the synthesis of some complexes as a neutral ligand. In medicine, biuret can be used as pharmaceutical intermediates to preparation hypnotics, sedatives, and some special drugs which have the functions of diuresis and lowering the blood pressure. In chemical industry, biuret plays an important role in the produce of the flame retardants of papers, the fiber bleaching agent, the paint of textiles, the foaming agent of foamed plastics, and the additive agent of the paint, adhesives, resins, plastics, dyes, and lubricating oils, and so on. In agriculture, biuret can be utilized as long-effective fertilizers rich in nitrogen. In animal husbandry, biuret is an excellent nonprotein nitrogen feed additive, and it has a better palatability and higher-usage comparing with urea which is usually used as feed additive. Several teams had synthesized and characterized the complexes of rare earth metals [1], actinide metals [2,3], and alkaline earth metals [4] based on biuret ligand. However, the complexes of transition metals with biuret ligand have been rarely reported $[5,6]$, particularly in the comparison between different metal ions on the synthesis of the biuret complexes. With the rapid development of animal industry in China, the prospects of biuret complexes which are used as feed additives for ruminants are considerable. The complexes of trace elements with biuret which are added in the feed of ruminants can play a dual role in supplementing both trace elements and nonprotein nitrogen, which can promote the growth of animals and improve the economic efficiency. Here we report the synthesis of four biuret complexes, study their optical properties, and characterize them by elemental analyses, UV, FTIR, Raman spectra, X-ray powder diffraction, and thermogravimetric analysis.

\section{Experimental}

2.1. Materials and Physical Measurements. All chemicals purchased were of analytical reagent grade and used without further purification. Nickel acetate, nickel chloride, manganese acetate, manganese chloride, and biuret were purchased from Sinopharm Chemical Reagent Co. Ltd. of Shanghai.

Elemental analyses for $\mathrm{C}, \mathrm{H}, \mathrm{N}$, and $\mathrm{O}$ in the complexes were measured on a Vario EL CUBE elemental analyzer, and the content of nickel and manganese was determined by EDTA complexometric titration with murexide and chrome black $\mathrm{T}$ as indicators, respectively. UV spectra were performed on a UV-3150 spectrophotometer. IR spectra were 
TABLE 1: Elemental analysis results of the complexes (calculated values are in brackets).

\begin{tabular}{lccccccc}
\hline Complex & Formula & $M_{r}$ & $w(\mathrm{M}) / \%$ & $w(\mathrm{C}) / \%$ & $w(\mathrm{H}) / \%$ & $w(\mathrm{O}) / \%$ & $w(\mathrm{~N}) / \%$ \\
\hline $\mathbf{1}$ & $\mathrm{NiC}_{8} \mathrm{H}_{22} \mathrm{O}_{11} \mathrm{~N}_{6}$ & 436.97 & $13.29(13.43)$ & $22.03(21.97)$ & $5.17(5.09)$ & $40.36(40.28)$ & $19.15(19.23)$ \\
$\mathbf{2}$ & $\mathrm{NiC}_{4} \mathrm{H}_{10} \mathrm{O}_{4} \mathrm{~N}_{6} \mathrm{Cl}_{2}$ & 335.75 & $17.62(17.48)$ & $14.48(14.30)$ & $2.96(3.01)$ & $18.99(19.06)$ & $24.92(25.04)$ \\
$\mathbf{3}$ & $\mathrm{MnC}_{8} \mathrm{H}_{19} \mathrm{O}_{9.5} \mathrm{~N}_{6}$ & 406.19 & $10.79(13.53)$ & $23.19(23.63)$ & $3.69(4.72)$ & $43.34(37.42)$ & $28.79(20.70)$ \\
$\mathbf{4}$ & $\mathrm{MnC}_{4} \mathrm{H}_{10} \mathrm{O}_{4} \mathrm{~N}_{6} \mathrm{Cl}_{2}$ & 332.00 & $16.42(16.55)$ & $14.39(14.46)$ & $2.98(3.04)$ & $19.35(19.28)$ & $24.41(25.32)$ \\
\hline
\end{tabular}

obtained with $\mathrm{KBr}$ pellets on a Nicolet 5700 FT-IR spectrophotometer in the range of $4000-400 \mathrm{~cm}^{-1}$. Raman spectra were recorded on an InVia Laser Raman spectrometer. The powder X-ray diffraction data were collected on a D/maxII X-ray diffractometer with $\mathrm{Cu} \mathrm{K}_{\alpha 1}$ radiation, the voltage of $35 \mathrm{kV}$, the current of $60 \mathrm{~mA}$, and the scanning speed of $8^{\circ} \mathrm{min}^{-1}$, in the diffraction angle range of $10-80^{\circ}$. The thermogravimetric analysis data were obtained using a SDT Q600 thermogravimetry analyzer in the air atmosphere in the temperature range of $25-800^{\circ} \mathrm{C}$ with a heating rate of $10^{\circ} \mathrm{C} \mathrm{min}^{-1}$.

2.2. Synthesis of $\left[\mathrm{Ni}(\text { bi })_{2}\left(\mathrm{H}_{2} \mathrm{O}\right)_{2}\right](\mathrm{Ac})_{2} \cdot \mathrm{H}_{2} \mathrm{O}$ (1). $\mathrm{Ni}(\mathrm{Ac})_{2}$. $4 \mathrm{H}_{2} \mathrm{O}(2.49 \mathrm{~g}, 10 \mathrm{mmol})$ and biuret $(2.06 \mathrm{~g}, 20 \mathrm{mmol})$ were weighed and dissolved in $80 \mathrm{~mL}$ methanol, and the solution was green. The mixed solution was stirred on a magnetic stirrer for about $6 \mathrm{~h}$ under reflux reaction. After the solution cooling, the resultant was separated from the reaction mixture by filtration and washed by some methanol and dried in the phosphorus pentoxide desiccator for 1 week. The product was green powder ( $3.59 \mathrm{~g})$ and the yield was about $82.2 \%$.

2.3. Synthesis of $\left[\mathrm{Ni}(\mathrm{bi})_{2} \mathrm{Cl}_{2}\right]$ (2). Complex 2 was synthesized by the same procedure as that for the synthesis of complex 1 except for using $\mathrm{NiCl}_{2} \cdot 6 \mathrm{H}_{2} \mathrm{O}(2.38 \mathrm{~g}, 10 \mathrm{mmol})$ instead of $\mathrm{Ni}(\mathrm{Ac})_{2} \cdot 4 \mathrm{H}_{2} \mathrm{O}$ as the start reactant. The product was green powder $(2.18 \mathrm{~g})$ and the yield was about $64.9 \%$.

2.4. Synthesis of $\left[\mathrm{Mn}(\mathrm{bi})_{2}(\mathrm{Ac})_{2}\right] \cdot 1.5 \mathrm{H}_{2} \mathrm{O}$ (3). The synthesis of complex 3 was similar to that of 1 except that $\mathrm{Mn}(\mathrm{Ac})_{2} \cdot 4 \mathrm{H}_{2} \mathrm{O}$ $(2.45 \mathrm{~g}, 10 \mathrm{mmol})$ was used to replace $\mathrm{Ni}(\mathrm{Ac})_{2} \cdot 4 \mathrm{H}_{2} \mathrm{O}$. There was a difference that the reaction mixture was cooling in the refrigerator. The solubility of complex 3 at room temperature was larger than that of complexes $\mathbf{1}$ and $\mathbf{2}$, and the yield was higher at low temperature. The product was pale pink powder $(2.37 \mathrm{~g})$ and the yield was about $58.3 \%$.

2.5. Synthesis of $\left[\mathrm{Mn}(\mathrm{bi})_{2} \mathrm{Cl}_{2}\right]$ (4). The synthetic method of 4 was the same as 3 other than that $\mathrm{Mn}(\mathrm{Ac})_{2} \cdot 4 \mathrm{H}_{2} \mathrm{O}$ was replaced by $\mathrm{MnCl}_{2} \cdot 4 \mathrm{H}_{2} \mathrm{O}(1.98 \mathrm{~g}, 10 \mathrm{mmol})$. The product was pale pink powder $(2.00 \mathrm{~g})$ and the yield was about $60.2 \%$.

\section{Result and Discussion}

3.1. Composition and Property. The results of elemental analyses for the complexes are shown in Table 1. The experimental results coincide with the theoretical calculation, and the composition of the complexes is $\left[\mathrm{Ni}(\mathrm{bi})_{2}\left(\mathrm{H}_{2} \mathrm{O}\right)_{2}\right](\mathrm{Ac})_{2} \cdot \mathrm{H}_{2} \mathrm{O}$, $\left[\mathrm{Ni}(\mathrm{bi})_{2} \mathrm{Cl}_{2}\right],\left[\mathrm{Mn}(\mathrm{bi})_{2}(\mathrm{Ac})_{2}\right] \cdot 1.5 \mathrm{H}_{2} \mathrm{O}$, and $\left[\mathrm{Mn}(\mathrm{bi})_{2} \mathrm{Cl}_{2}\right](\mathrm{bi}$
$=\mathrm{NH}_{2} \mathrm{CONHCONH}_{2}$ ), respectively. In order to make sure whether chlorine atoms were coordinated or ionic, a qualitative test was conducted; namely, a few drops of $\mathrm{AgNO}_{3}$ solution were added into the aqueous solution containing complexes 2 and 4; there was no precipitation formation. This indicates that the chlorine atoms are coordinated to the metal ions rather than ionic. The solid complexes are stable in the air, easily dissolved in water, and not easy to absorb moisture. Every $\mathrm{Ni}$ (II) ion in complex $\mathbf{1}$ is coordinated by six oxygen atoms from two biuret molecules and two coordinated water molecules, while $\mathrm{Ni}$ (II) and $\mathrm{Mn}$ (II) ions in complexes 2 and 4 are coordinated with two chloride ions and four oxygen atoms from two biuret molecules. In contrast, the $\mathrm{Mn}$ (II) ion in complex 3 is coordinated by six oxygen atoms from two biuret molecules and two acetate anions. Several complexes in which the acetate anions are coordinated had been reported [7-9]. In the four complexes, six coordinated atoms form an octahedral geometry, and four oxygen atoms presenting quadrilateral from two biuret are in the same plane with the metal ions. The other two coordinated atoms are on both sides of the plane. The metal ions are in the centre of the octahedron. And the octahedron is symmetric; thus, the structures of the complexes are stable.

3.2. UV Spectroscopy Analysis. The UV spectra of the complexes and biuret are shown in Figure 1. It is not difficult to find that there is an absorption peak around $200 \mathrm{~nm}$ for biuret as well as the four complexes we have synthesized, which shows a close spectral similarity between the four complexes and biuret. In other words, the UV absorption of the complexes derived from biuret. The very strong absorption at short wavelengths is attributed to $\pi-\pi^{*}$ transitions, originating from the carbonyl groups of biuret ligand. The locations of the UV absorption peaks for these complexes are found to be a bit different, indicating that some changes in the $\pi$-electron system of biuret have taken place. The outer electronic structure of $\mathrm{Ni}^{2+}$ is $3 \mathrm{~d}^{8}$, and there is no empty $3 \mathrm{~d}$ orbit. Compared with $\mathrm{Ni}^{2+}$, the outer electronic structure of $\mathrm{Mn}^{2+}$ is $3 \mathrm{~d}^{5}$, and there are two empty $3 \mathrm{~d}$ orbits. As a result, the electrons of $\mathrm{Cl}^{-}$in $3 \mathrm{p}$ orbits can be filled into the empty $3 \mathrm{~d}$ orbits of $\mathrm{Mn}^{2+}$. Therefore, the UV spectrum of complex 4 differs from those of other studied complexes and the free biuret ligand. In conclusion, the oxygen atoms of the carbonyl groups in biuret molecules are coordinated to the metal ions.

3.3. IR Spectroscopy Analysis. The IR spectra of the four complexes and biuret are shown in Figures 2-4, and the main infrared spectral data of biuret and its complexes are listed in Table 2. In the spectra of the four complexes, two 
TABLE 2: Infrared spectra of the ligand and the complexes $\left(\mathrm{cm}^{-1}\right)$.

\begin{tabular}{|c|c|c|c|c|c|}
\hline bi & {$\left[\mathrm{Ni}(\mathrm{bi})_{2}\left(\mathrm{H}_{2} \mathrm{O}\right)_{2}\right](\mathrm{Ac})_{2} \cdot \mathrm{H}_{2} \mathrm{O}$} & {$\left[\mathrm{Ni}(\mathrm{bi})_{2} \mathrm{Cl}_{2}\right]$} & {$\left[\mathrm{Mn}(\mathrm{bi})_{2}(\mathrm{Ac})_{2}\right] \cdot 1.5 \mathrm{H}_{2} \mathrm{O}$} & {$\left[\mathrm{Mn}(\mathrm{bi})_{2} \mathrm{Cl}_{2}\right]$} & Vibration type \\
\hline 3415 & 3433,3379 & 3383 & 3406 & 3406 & $v_{\text {as }}\left(\mathrm{NH}_{2}\right)+v\left(\mathrm{H}_{2} \mathrm{O}\right) / v_{\text {as }}\left(\mathrm{NH}_{2}\right)$ \\
\hline 3254 & 3196,3115 & 3268,3198 & 3216 & 3264,3196 & $\nu_{\mathrm{s}}\left(\mathrm{NH}_{2}\right)$ \\
\hline 1719 & 1686 & 1693 & 1693 & 1685 & $\nu(\mathrm{C}=\mathrm{O})$ \\
\hline 1585 & 1530 & 1582 & 1551 & 1571 & $\delta\left(\mathrm{NH}_{2}\right)$ \\
\hline 1499,1423 & 1445,1411 & 1490 & 1512 & 1485 & $\nu(\mathrm{C}-\mathrm{N})+\nu\left(\mathrm{C}-\mathrm{NH}_{2}\right)$ \\
\hline 1323 & 1343 & 1336 & 1336 & 1329 & $\delta(\mathrm{N}-\mathrm{H})$ \\
\hline 1130 & 1126 & 1127 & 1140 & 1120 & $\nu(\mathrm{C}-\mathrm{N})+\delta(\mathrm{N}-\mathrm{H})$ \\
\hline 1081 & 1054 & 1100 & 1099 & 1092 & $\nu(\mathrm{C}-\mathrm{N})$ \\
\hline 946 & 923 & 943 & 925 & 939 & $v(\mathrm{C}-\mathrm{N})+v\left(\mathrm{C}-\mathrm{NH}_{2}\right)$ \\
\hline 770 & 781 & 760 & 780 & 757 & $\delta\left(\mathrm{C}-\mathrm{NH}_{2}\right)$ \\
\hline 710 & 646 & 646 & 634 & 621 & $\delta(\mathrm{C}=\mathrm{O})$ \\
\hline
\end{tabular}

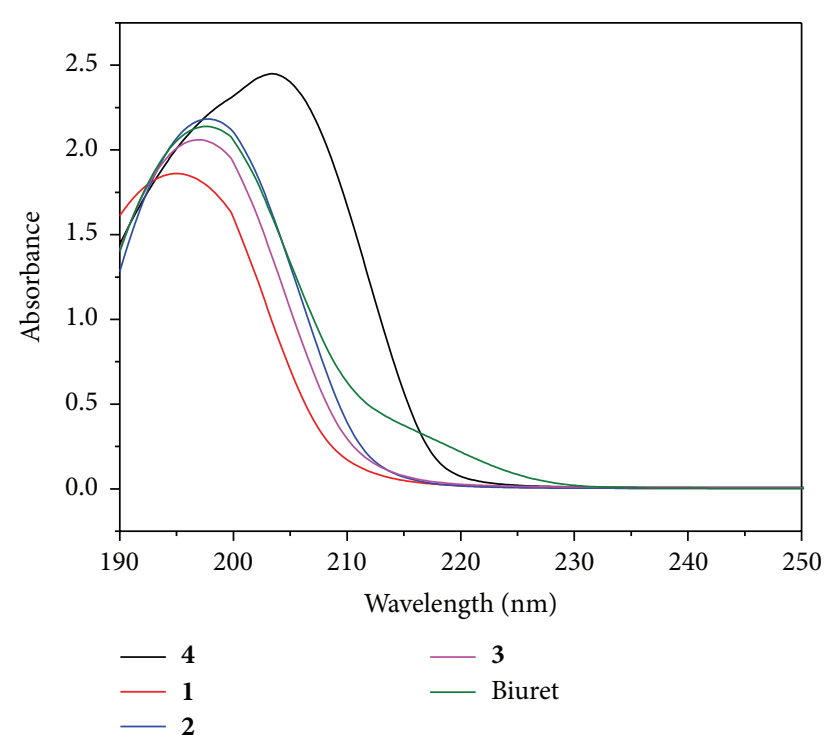

FIGURE 1: UV spectra of the complexes and biuret.

bands $\left(3115-3430 \mathrm{~cm}^{-1}\right.$ ) are observed in the $\mathrm{N}-\mathrm{H}$ stretching region. The former one is alternatively assigned to bridging hydroxide whereas the water of hydration band appears near $3400 \mathrm{~cm}^{-1}$ in complexes 1 and 3. The $\mathrm{N}-\mathrm{H}$ deformation vibrations are observed at $1530 \mathrm{~cm}^{-1}$ with significant intensities. The carbonyl stretching frequencies in compounds containing the $\mathrm{CO}-\mathrm{NH}-\mathrm{CO}$ group are reported to give rise to two bands $[10,11]$, the asymmetric stretching vibration peak appears above $1700 \mathrm{~cm}^{-1}$, and the symmetric vibration peak appears near $1700 \mathrm{~cm}^{-1}$. When coordination occurs it determines the amount of electron delocalization in the $\mathrm{N}-\mathrm{CO}-\mathrm{N}$ system; thus, coordination through the oxygen atom will produce a decrease in the double bond character of the $\mathrm{C}=\mathrm{O}$ bonds and conduct a shift of the carbonyl stretching mode to lower frequencies [12]. The stretching vibration peaks of the $\mathrm{C}=\mathrm{O}$ bonds in the complexes are detected at $1686,1693,1693$, and $1685 \mathrm{~cm}^{-1}$, respectively, which are a little lower than the frequency of biuret $\left(1719 \mathrm{~cm}^{-1}\right)$. It is

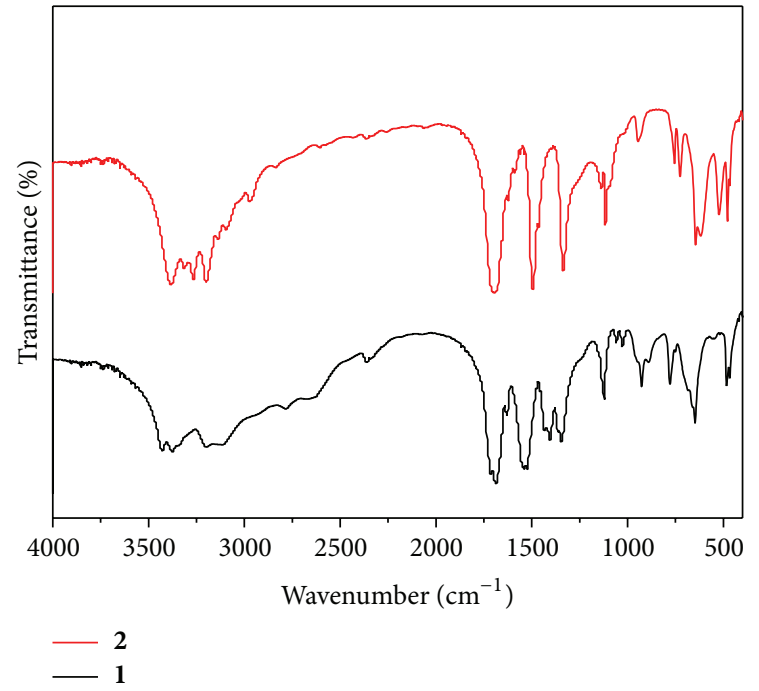

FIGURE 2: IR spectra of complexes 1 and 2.

believed that the unprotonated biuret $\mathrm{M}(\mathrm{II})(\mathrm{M}=\mathrm{Ni}, \mathrm{Mn})$ complexes should have the $\mathrm{M}-\mathrm{O}$ coordinated bonds. On the other hand, the bending vibration peaks of the $\mathrm{C}=\mathrm{O}$ bonds found in the region of $621-664 \mathrm{~cm}^{-1}$ are the evidence of the coordination between metal ions and oxygen atoms in the ligand as well. In the nickel complexes, the frequency of the stretching vibration peak of the $\mathrm{C}=\mathrm{O}$ bonds in complex 1 containing acetate anions is a little lower than that of complex 2 containing chloride anions. However, in the manganese complexes, it is higher in complex $\mathbf{3}$ containing acetate anions than that of complex 4 containing chloride anions. Compared with complex 1 , the stretching vibration peak of the $\mathrm{C}=\mathrm{O}$ bonds in complex 3 moves to high wavenumber, which can illustrate that both the oxygen atoms in biuret molecules and acetate anions are coordinated to the manganese ions in complex 3. The absorption peaks at $476 \mathrm{~cm}^{-1}$ in complexes 1 and $\mathbf{2}$ are originated to the stretching vibrations of the $\mathrm{Ni}-\mathrm{O}$ bonds, and the absorption peaks at $459 \mathrm{~cm}^{-1}$ in complexes 3 and 4 are the characteristic peaks of the $\mathrm{Mn}-\mathrm{O}$ bonds [13-17]. 


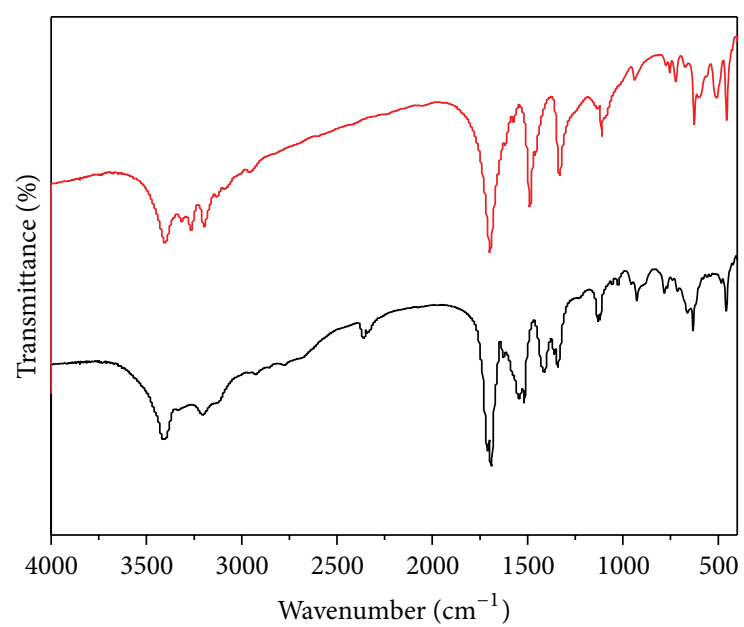

$-3$

Figure 3: IR spectra of complexes 3 and 4.

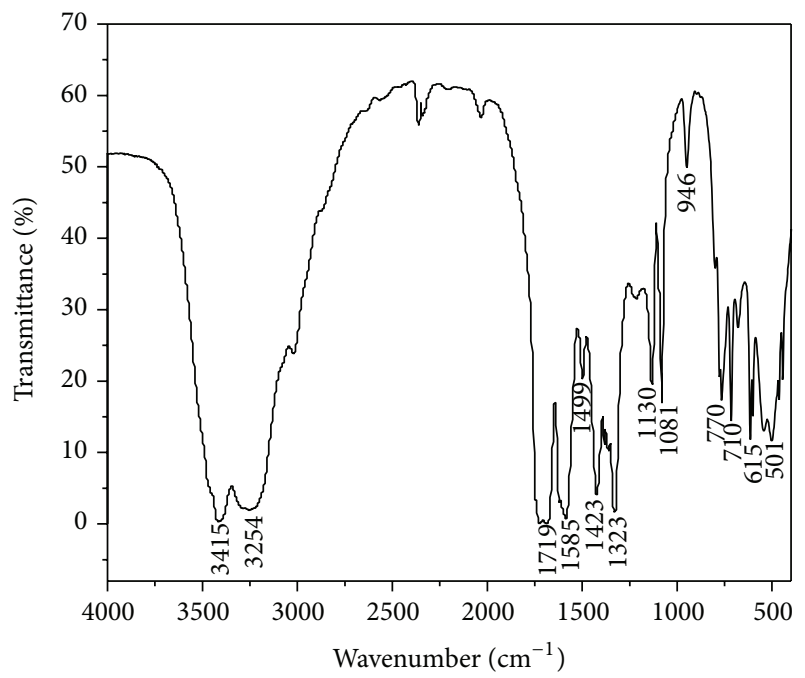

Figure 4: IR spectrum of biuret.

3.4. Raman Spectroscopy Analysis. Figures 5 and 6 show the Raman spectra of the complexes obtained in the $400-4000 \mathrm{~cm}^{-1}$ range, and the frequencies data of the biuret and its complexes are listed in Table 3. Obviously, there are many correlations among peaks when comparing the Raman spectra with the IR spectra. For example, the wide absorption peaks in the four complexes from the stretching vibrations of the $\mathrm{O}-\mathrm{H}$ and $\mathrm{N}-\mathrm{H}$ bonds appear in the region of $3430-3200 \mathrm{~cm}^{-1}$ in the IR spectra as well as in the Raman spectra. But some differences can be discovered that the bending vibration peaks of the $\mathrm{N}-\mathrm{H}$ bond near $1320 \mathrm{~cm}^{-1}$ in the Raman spectra are found to be quite weak and even cannot be found comparing with those in the IR spectra. The result may be explained that the $\mathrm{N}-\mathrm{H}$ bond in biuret is a polar bond, and it is Raman negative. It is well known that when the interaction between the metal cations $\left(\mathrm{M}^{2+}\right)$ and the coordinated water molecules is strong enough, a Raman

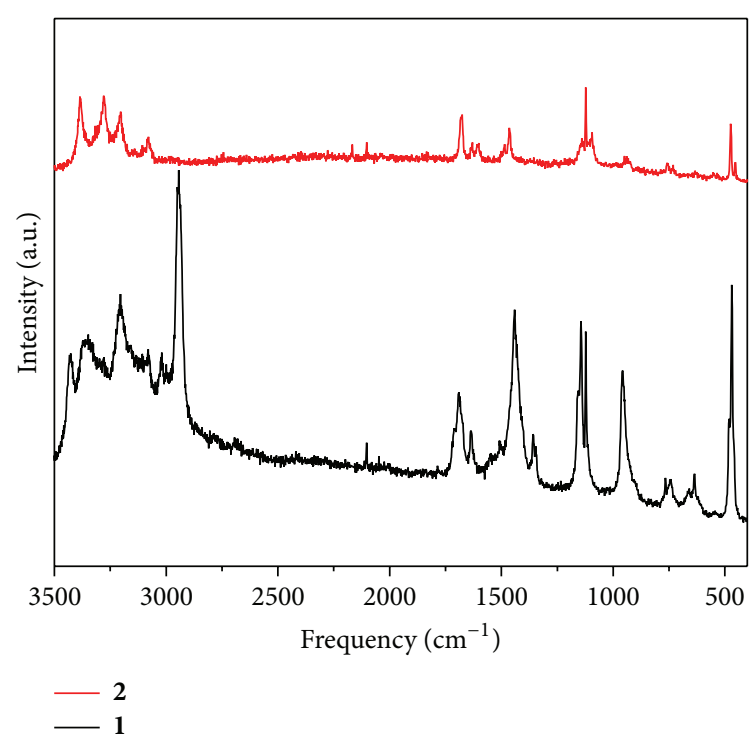

FIGURE 5: Raman spectra of complexes 1 and 2.

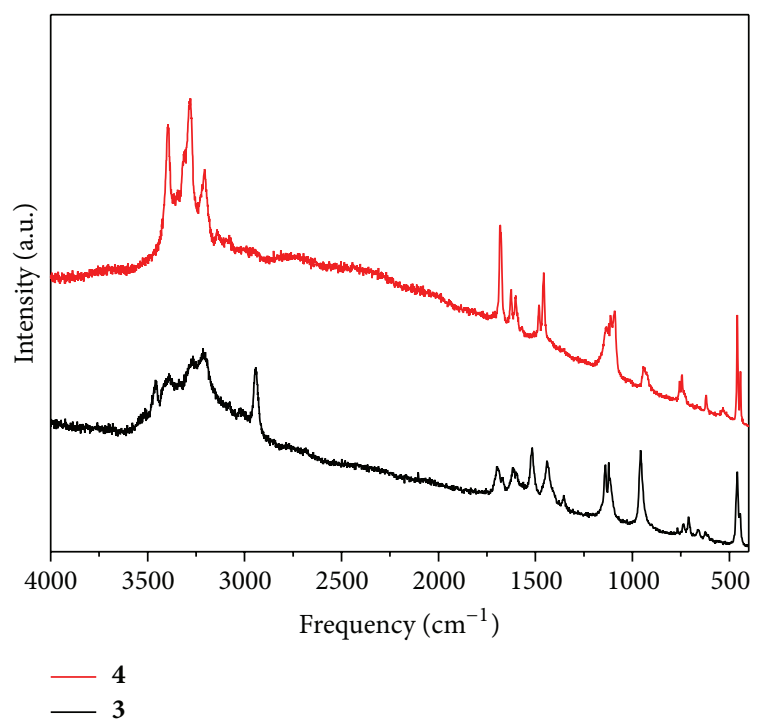

FIGURE 6: Raman spectra of complexes 3 and 4.

band due to the symmetric stretching vibration of $\mathrm{M}-\mathrm{OH}_{2}$ is observed in the low-frequency region from 300 to $550 \mathrm{~cm}^{-1}$ [18-22]. The absorption peak at $467 \mathrm{~cm}^{-1}$ for complex $\mathbf{1}$ is assigned to the symmetric $\mathrm{M}-\mathrm{OH}_{2}$ stretching vibration.

3.5. X-Ray Powder Diffraction Analysis. X-ray powder diffraction (XRD) is measured to confirm the phase purity of the samples. The XRD patterns of the complexes and the ligand are shown in Figures 7-9. The background of the XRD patterns is small and the diffractive intensity is strong, indicating that the complex has a fine crystalline state. The strong peak locations of the complexes are shown in Table 4, which are obviously changed comparing with biuret and nickel acetate (JCPDS 26-1282) or nickel chloride (JCPDS 22-0765), manganese acetate (JCPDS 29-0879), 
TABLE 3: Raman spectra of the complexes $\left(\mathrm{cm}^{-1}\right)$.

\begin{tabular}{lccccc}
\hline bi & {$\left[\mathrm{Ni}(\mathrm{bi})_{2}\left(\mathrm{H}_{2} \mathrm{O}\right)_{2}\right](\mathrm{Ac})_{2} \cdot \mathrm{H}_{2} \mathrm{O}$} & {$\left[\mathrm{Ni}(\mathrm{bi})_{2} \mathrm{Cl}_{2}\right]$} & {$\left[\mathrm{Mn}(\mathrm{bi})_{2}(\mathrm{Ac})_{2}\right] \cdot 1.5 \mathrm{H}_{2} \mathrm{O}$} & {$\left[\mathrm{Mn}(\mathrm{bi})_{2} \mathrm{Cl}_{2}\right]$} & Vibration type \\
\hline 3370 & 3433 & 3382 & 3398 & 3398 & $\nu_{\text {as }}\left(\mathrm{NH}_{2}\right)+\nu\left(\mathrm{H}_{2} \mathrm{O}\right) / \nu_{\text {as }}\left(\mathrm{NH}_{2}\right)$ \\
3230 & 3203 & 3276 & 3210 & 3282 & $\nu_{\mathrm{s}}\left(\mathrm{NH}_{2}\right)$ \\
1690 & 1691 & 1685 & 1698 & 1685 & $\nu(\mathrm{C}=\mathrm{O})$ \\
1440 & 1439 & 1467 & 1441 & 1460 & $\nu(\mathrm{C}-\mathrm{N})+\nu\left(\mathrm{C}-\mathrm{NH} \mathrm{H}_{2}\right)$ \\
1150 & 1134 & 1123 & 1129 & 936 & $\nu(\mathrm{C}-\mathrm{N})+\delta(\mathrm{N}-\mathrm{H})$ \\
965 & 955 & 938 & 956 & 748 & $\nu(\mathrm{C}-\mathrm{N})+\nu\left(\mathrm{C}-\mathrm{NH}_{2}\right)$ \\
775 & 750 & 750 & 709 & 619 & $\delta\left(\mathrm{C}-\mathrm{NH}_{2}\right)$ \\
647 & 638 & 627 & 618 & 463 & $\delta(\mathrm{C}=\mathrm{O})$ \\
- & 467 & 473 & 456 & & $\nu(\mathrm{M}-\mathrm{O})$ \\
\hline
\end{tabular}

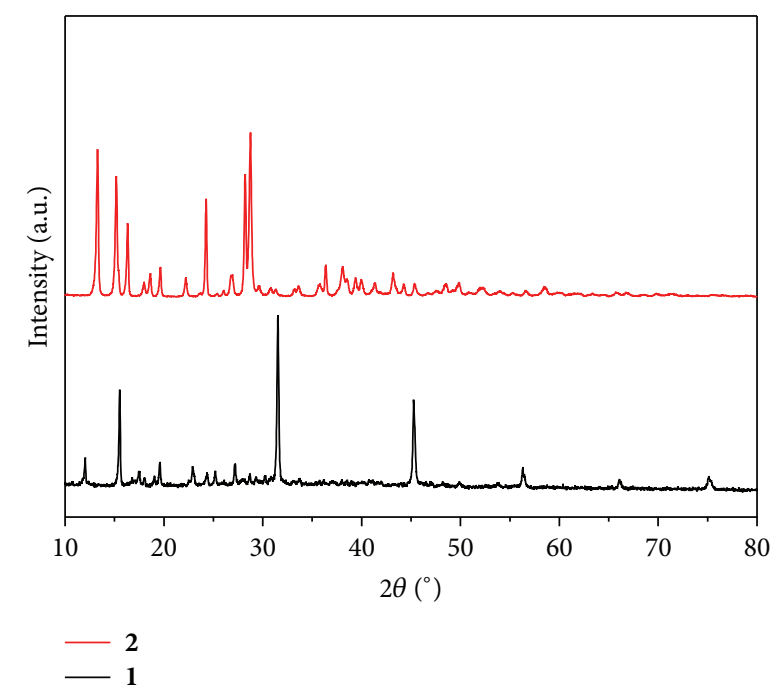

Figure 7: X-ray powder diffraction patterns of complexes 1 and 2.

and manganese chloride (JCPDS 22-0721). All these strong peaks of the reactants are disappeared in the X-ray powder diffraction patterns of the complexes. The diffraction angle $(2 \theta)$, diffractive intensity, and spacing $(d)$ of the products are completely different from the reactive materials, which may illuminate that the resultants are new compounds instead of the reactant mixture [23].

3.6. Thermogravimetric Analysis. The thermal behavior of the four complexes is studied from $25^{\circ} \mathrm{C}$ to $800^{\circ} \mathrm{C}$ under air. The TG-DTG curves are shown in Figures 10-13. The TG analysis (Figure 10) reveals that complex $\mathbf{1}$ is decomposed through four major processes, namely, the loss of lattice water molecules, the coordinated water molecules, and the combustion of biuret ligand and nickel acetate. The first weight loss is approximately $4.27 \%$ (calcd. $4.12 \%$ ) in the range of $64-105^{\circ} \mathrm{C}$, corresponding to the weight of one lattice water molecule. There is a weight loss of $8.03 \%$ near $137^{\circ} \mathrm{C}$ for complex $\mathbf{1}$, which is ascribed to the loss of two coordinated water molecules, and the measured value is in agreement with the calculated one (8.25\%). The third weight loss occurs between $153^{\circ} \mathrm{C}$ and $514^{\circ} \mathrm{C}$ and is characteristic of the combustion of biuret ligand (found $47.58 \%$, calcd. $47.17 \%$ ).

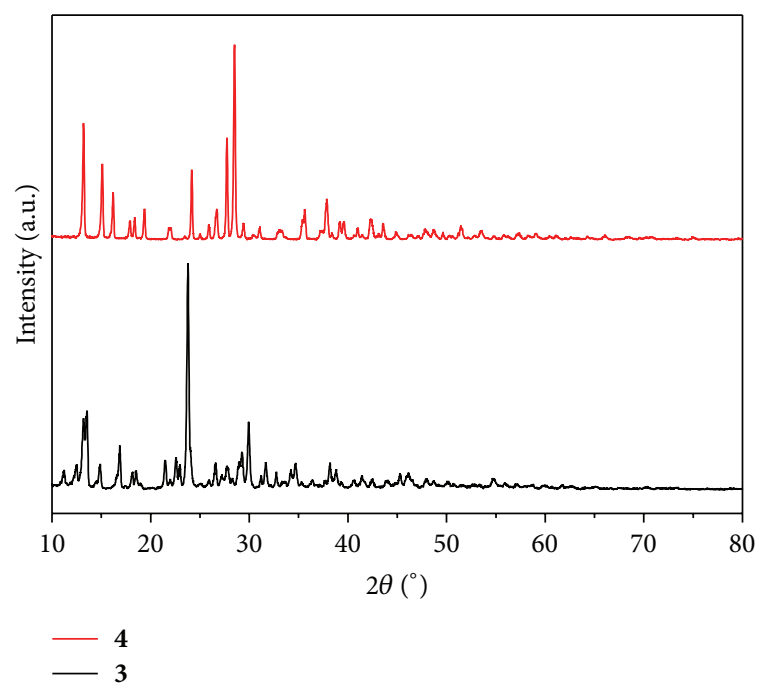

FIgURE 8: X-ray powder diffraction patterns of complexes 3 and 4.

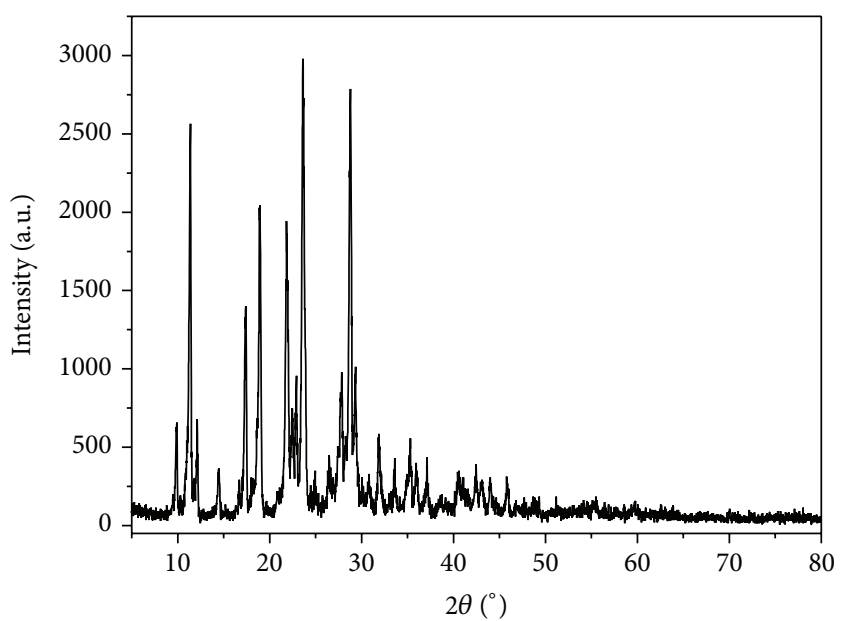

FIGURE 9: X-ray powder diffraction pattern of biuret.

The last weight loss is considered to be the decomposition of nickel acetate (found $23.25 \%$, calcd. $23.36 \%$ ). As a result, the final residue is nickel oxide. As shown in Figure 11, there are two large weight losses of $60.67 \%$ (calcd. $61.40 \%$, loss of two 
TABLE 4: The data for X-ray powder diffraction patterns of the complexes and biuret.

\begin{tabular}{|c|c|c|c|c|c|}
\hline \multirow{2}{*}{$\begin{array}{l}\text { Compound } \\
\text { bi }\end{array}$} & \multicolumn{5}{|c|}{ The $2 \theta\left(^{\circ}\right)$ locations of the main strong peaks (relative intensities are in brackets) } \\
\hline & $23.51(100)$ & $28.71(94)$ & $11.30(86)$ & $18.88(69)$ & $21.83(65)$ \\
\hline$\left[\mathrm{Ni}(\mathrm{bi})_{2}\left(\mathrm{H}_{2} \mathrm{O}\right)_{2}\right](\mathrm{Ac})_{2} \cdot \mathrm{H}_{2} \mathrm{O}$ & $31.50(100)$ & $15.45(60)$ & $45.18(56)$ & $12.06(24)$ & $19.51(22)$ \\
\hline$\left[\mathrm{Ni}(\mathrm{bi})_{2} \mathrm{Cl}_{2}\right]$ & $28.68(100)$ & $13.18(90)$ & $28.23(75)$ & $15.19(74)$ & $24.27(61)$ \\
\hline$\left[\mathrm{Mn}(\mathrm{bi})_{2}(\mathrm{Ac})_{2}\right] \cdot 1.5 \mathrm{H}_{2} \mathrm{O}$ & $23.78(100)$ & $13.52(35)$ & $13.13(32)$ & $29.92(30)$ & $16.86(20)$ \\
\hline$\left[\mathrm{Mn}(\mathrm{bi})_{2} \mathrm{Cl}_{2}\right]$ & $28.45(100)$ & $13.13(60)$ & $27.58(49)$ & 14.99 (39) & $24.12(36)$ \\
\hline $\mathrm{Ni}(\mathrm{Ac})_{2} \cdot 4 \mathrm{H}_{2} \mathrm{O}$ & $12.93(100)$ & $18.62(30)$ & $28.34(20)$ & $22.13(19)$ & $21.09(13)$ \\
\hline $\mathrm{NiCl}_{2} \cdot 6 \mathrm{H}_{2} \mathrm{O}$ & $15.26(100)$ & $36.24(79)$ & $30.08(30)$ & $51.78(18)$ & $52.58(17)$ \\
\hline $\mathrm{Mn}(\mathrm{Ac})_{2} \cdot 4 \mathrm{H}_{2} \mathrm{O}$ & $9.068(100)$ & $11.59(32)$ & $12.18(25)$ & $26.20(8)$ & $27.55(8)$ \\
\hline $\mathrm{MnCl}_{2} \cdot 4 \mathrm{H}_{2} \mathrm{O}$ & $17.93(100)$ & $20.03(75)$ & $30.67(75)$ & $34.54(45)$ & $16.04(40)$ \\
\hline
\end{tabular}

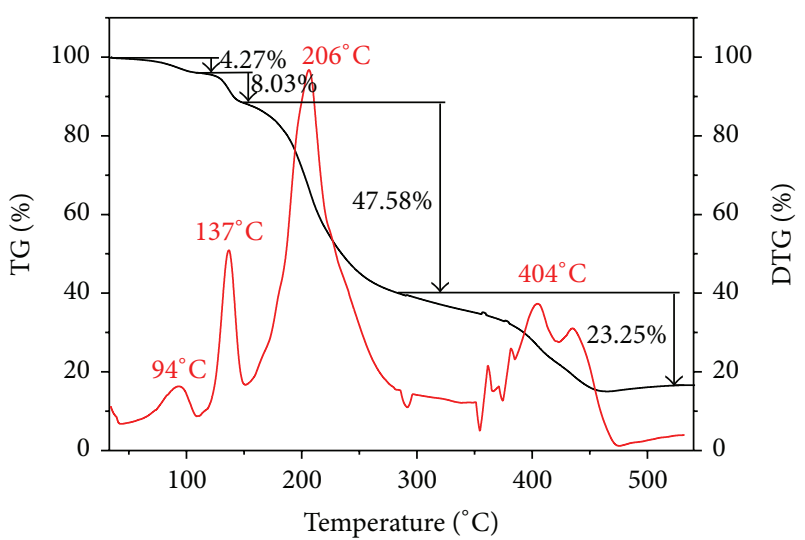

FIgURE 10: TG-DTG curves of complex 1.

biuret molecules) and $16.73 \%$ (calcd. 16.35\%, decomposition of nickel chloride) for complex 2 , and the residual weight in the TG curve is $22.60 \%$, which agrees with the theoretical value $(22.25 \%)$, and the final residue is determined as nickel oxide. Complex 4 is similar to complex 2 . There are two stages weight losses with the increasing of the temperature, namely, the combustion of biuret ligand (found $61.88 \%$, calcd. $62.10 \%$ ) and the oxidation of manganese chloride (found $16.24 \%$, calcd. $16.53 \%$ ), and the final residue is $\mathrm{MnO}$ (found $21.88 \%$, calcd. $21.37 \%$ ). Compared with three other complexes, complex 3 undergoes three weight losses of $6.85 \%$, $49.65 \%$, and $25.5 \%$ near $104^{\circ} \mathrm{C}, 215^{\circ} \mathrm{C}$, and $485^{\circ} \mathrm{C}$, respectively, and the first two weight losses agree with the loss of $1.5 \mathrm{H}_{2} \mathrm{O}$ (calcd. 6.65\%) and two biuret molecules (calcd. 49.65\%). The last weight losses are considered to be the decomposition of manganese acetate (found $25.40 \%$, calcd. $25.14 \%$ ) and the final residue is $\mathrm{MnO}$ (found $18.10 \%$, calcd. $17.46 \%$ ). All in all, the thermal behavior of the complexes corresponds to their composition.

\section{Conclusion}

In summary, the complexes $\left[\mathrm{Ni}(\mathrm{bi})_{2}\left(\mathrm{H}_{2} \mathrm{O}\right)_{2}\right](\mathrm{Ac})_{2} \cdot \mathrm{H}_{2} \mathrm{O}(\mathbf{1})$, $\left[\mathrm{Ni}(\mathrm{bi})_{2} \mathrm{Cl}_{2}\right](2),\left[\mathrm{Mn}(\mathrm{bi})_{2}(\mathrm{Ac})_{2}\right] \cdot 1.5 \mathrm{H}_{2} \mathrm{O}(3)$, and $\left[\mathrm{Mn}(\mathrm{bi})_{2} \mathrm{Cl}_{2}\right]$ (4) were successfully synthesized with nickel acetate or nickel chloride, manganese acetate, manganese chloride, and

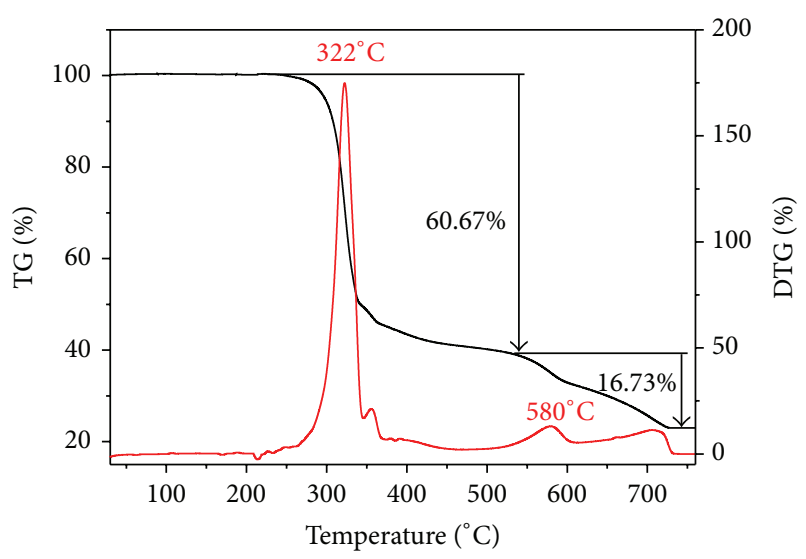

FIGURE 11: TG-DTG curves of complex 2.

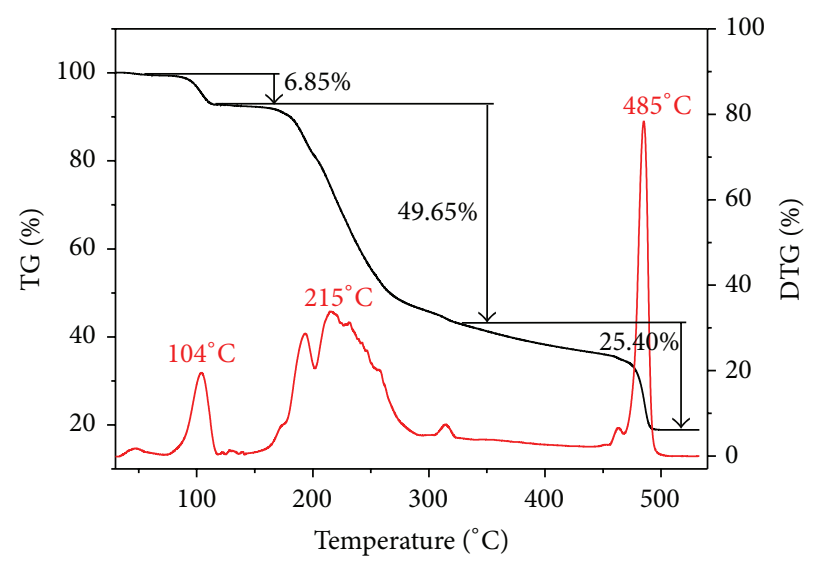

Figure 12: TG-DTG curves of complex 3.

biuret as raw materials. The four complexes of $\mathrm{Ni}(\mathrm{II})$ and $\mathrm{Mn}$ (II) were hexacoordinated. It was special that the acetate anions in complex 3 were coordinated to the $\mathrm{Mn}$ (II) ion, which was not common in most complexes. The optical properties of the complexes were studied via UV, FTIR, Raman spectra, and X-ray powder diffraction. The FTIR spectra were complementary to the Raman spectra, and the structures of the complexes were further verified. The thermal analysis results showed that the decomposition of complexes 1 


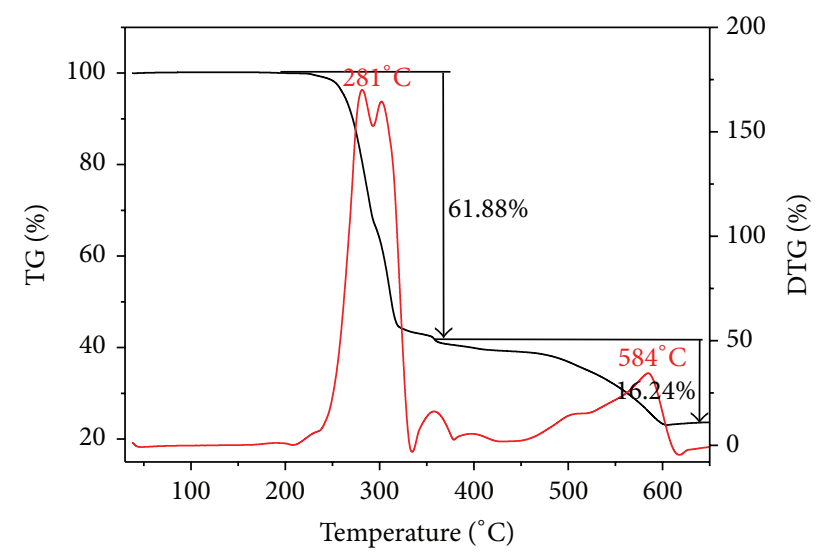

FIGURE 13: TG-DTG curves of complex 4.

and 3 contained the loss of water molecules, the oxidation and decomposition of biuret, and the oxidation of inorganic salts. The thermal decomposition processes of complexes $\mathbf{2}$ and $\mathbf{4}$ are thought to be only the oxidation and decomposition of biuret and the oxidation of inorganic salts, in which there is no water molecule. The final residues were $\mathrm{NiO}$ for complexes $\mathbf{1}$ and $\mathbf{2}$ and $\mathrm{MnO}$ for complexes $\mathbf{3}$ and $\mathbf{4}$.

\section{Conflict of Interests}

The authors declare that there is no conflict of interests regarding the publication of this paper.

\section{Acknowledgments}

This work was supported by the Scientific Research Funds of Education Department of Sichuan Province (10ZA016). The authors are very grateful to Analytical and Testing Center of Southwest University of Science and Technology and Engineering Research Center of Biomass Materials of Education Ministry for the testing of elemental analyses, XRD, UV, FTIR, Raman spectra, and TG-DTG.

\section{References}

[1] Y. L. Zhai, N. Tang, M. Y. Tan, G. M. Yu, and D. B. Wang, "Synthesis and properties of solid complexes between lanthanide nitrates and biuret," Chinese Journal of Inorganic Chemistry, vol. 2, no. 3, pp. 88-95, 1986.

[2] N. Tang, M. Y. Tan, Y. Li Zhai, and K. M. Wang, "Synthesis and characterization of the solid complex of thorium nitrate with biuret," Journal of Lanzhou University, vol. 22, no. 1, pp. 90-94, 1986.

[3] N. Tang, M. Y. Tan, Y. L. Zhai, and K. M. Wang, "Solid coordination compound of uranyl nitrate with biuret," Chinese Journal of Applied Chemistry, vol. 3, no. 4, pp. 13-16, 1986.

[4] S. Haddad and P. S. Gentile, "The crystal and molecular structure of tetrakis(biuret)strontium(II) perchlorate," Inorganica Chimica Acta, vol. 12, no. 1, pp. 131-138, 1975.

[5] G.-Q. Zhong and R.-Q. Zeng, "Synthesis of the complex of potassium bis(biureto) cuprate eetrahydrate by solid phase reaction," Chemical Research and Application, vol. 14, no. 4, pp. 461-462, 2002.

[6] G.-Q. Zhong and R.-Q. Zeng, "Syntheses of the copper(II) bomplexes of biuret by solid phase reaction with microwave radiation," Chinese Journal of Inorganic Chemistry, vol. 18, no. 8, pp. 849-853, 2002.

[7] A. I. Fischer, D. O. Ruzanov, M. Y. Gorlov, A. V. Shchukarev, A. N. Belyaev, and S. A. Simanova, "Synthesis, crystal and molecular structures of the octanuclear cationic mixed-valence cobalt acetate complex," Russian Journal of Coordination Chemistry, vol. 33, no. 11, pp. 789-794, 2007.

[8] T. Sato and F. Ambe, "An oxo-centered trinuclear cobalt(II)diiron(III) acetate-aqua complex," Acta Crystallographica Section C, vol. 52, pp. 3005-3007, 1996.

[9] G. Liu, B. Chen, and D. X. Chen, "Synthesis, crystal structure and ferromagnetic properties of a novel acetate bridged dicadmium(II) complex with nitronyl nitroxide," Russian Journal of Coordination Chemistry, vol. 37, no. 10, pp. 738-742, 2011.

[10] T. Uno and K. Machida, "Infrared spectra of succinimide and maleimide in the crystalline state," Bulletin of the Chemical Society of Japan, vol. 35, no. 2, pp. 276-283, 1962.

[11] C. S. Kraihanzel and S. C. Grenda, "Acyclic imides as ligands. I. Diacetamide complexes of manganese(II), iron(II), cobalt(II), nickel(II), copper(II), and zinc(II) perchlorates," Inorganic Chemistry, vol. 4, no. 7, pp. 1037-1042, 1965.

[12] M. R. Udupa and V. Indira, "Biuret complexes of copper(II) and nickel(II)," Journal of Indian Chemical Society, vol. 52, pp. 585$588,1975$.

[13] J. Dharmaraja, P. Subbaraj, T. Esakkidurai, and S. Shobana, "Coordination behavior and bio-potent aspects of $\mathrm{Ni}$ (II) with 2aminobenzamide and some amino acid mixed ligands-part II: synthesis, spectral, morphological, pharmacological and DNA interaction studies," Spectrochimica Acta Part A: Molecular and Biomolecular Spectroscopy, vol. 132, pp. 604-614, 2014.

[14] K. R. Sangeetha Gowda, H. S. Bhojya Naik, B. Vinay Kumar et al., "Synthesis, antimicrobial, DNA-binding and photonuclease studies of Cobalt(III) and Nickel(II) Schiff base complexes," Spectrochimica Acta Part A, vol. 105, pp. 229-237, 2013.

[15] M. S. Refat, "Spectroscopic and thermal degradation behavior of $\mathrm{Cr}(\mathrm{III}), \mathrm{Mn}$ (II), $\mathrm{Fe}(\mathrm{III}), \mathrm{Co}(\mathrm{II}), \mathrm{Ni}(\mathrm{II}), \mathrm{Cu}(\mathrm{II})$ and $\mathrm{Zn}$ (II) complexes with thiopental sodium anesthesia drug," Journal of Molecular Structure, vol. 1037, pp. 170-185, 2013.

[16] B. Cabir, B. Avar, M. Gulcan, A. Kayraldiz, and M. Kurtoglu, "Synthesis, spectroscopic characterization, and genotoxicity of a new group of azo-oxime metal chelates," Turkish Journal of Chemistry, vol. 37, no. 3, pp. 422-438, 2013.

[17] A. A. Soayed, H. M. Refaat, and D. A. Noor El-Din, "Metal complexes of moxifloxacin-imidazole mixed ligands: characterization and biological studies," Inorganica Chimica Acta, vol. 406, pp. 230-240, 2013.

[18] R. J. H. Clark and R. E. Hester, Advances in Infrared and Raman Spectroscopy, vol. 12, John Wiley \& Sons, New York, NY, USA, 1985.

[19] R. R. Dogonadze, E. Kalman, A. A. Kornyshev, and J. Ulstrup, The Chemical Physics of Solvation. Part B: Spectroscopy of Solvation, Elsevier Science, Amsterdam, The Netherlands, 1986.

[20] H. Kanno, "Hydrations of metal ions in aqueous electrolyte solutions: a Raman study," Journal of Physical Chemistry, vol. 92, no. 14, pp. 4232-4236, 1988.

[21] H. Kanno and H. Kanno, "Correlation of the Raman $v_{1}$ bands of aquated divalent metal ions with the cation-hydrated water 
distance," Journal of Raman Spectroscopy, vol. 18, pp. 301-304, 1987.

[22] H. Kanno and J. Hiraishi, "A Raman study of aqueous solutions of ferric nitrate, ferrous chloride and ferric chloride in the glassy state," Journal of Raman Spectroscopy, vol. 12, no. 3, pp. 224-227, 1982.

[23] D. Li and G.-Q. Zhong, "Synthesis and crystal structure of the bioinorganic complex [Sb(Hedta)]·2H2O," Bioinorganic Chemistry and Applications, vol. 2014, Article ID 461605, 7 pages, 2014. 

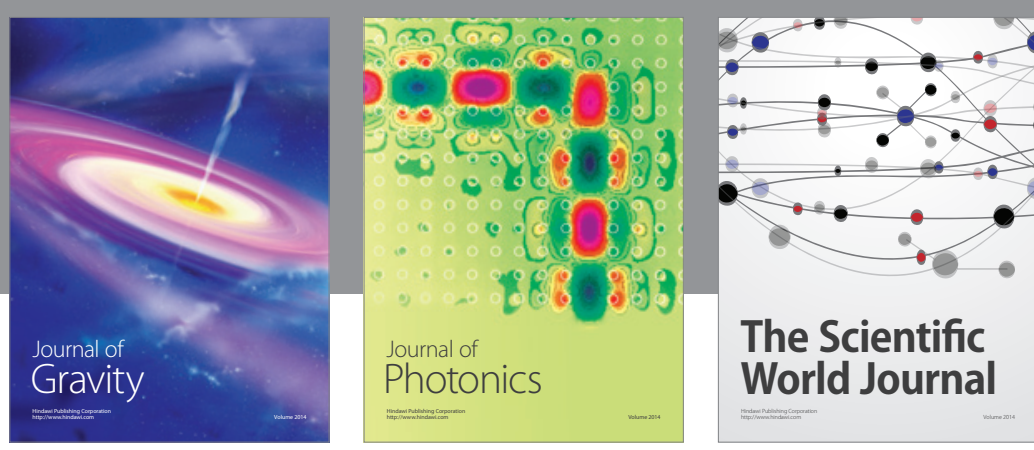

The Scientific World Journal
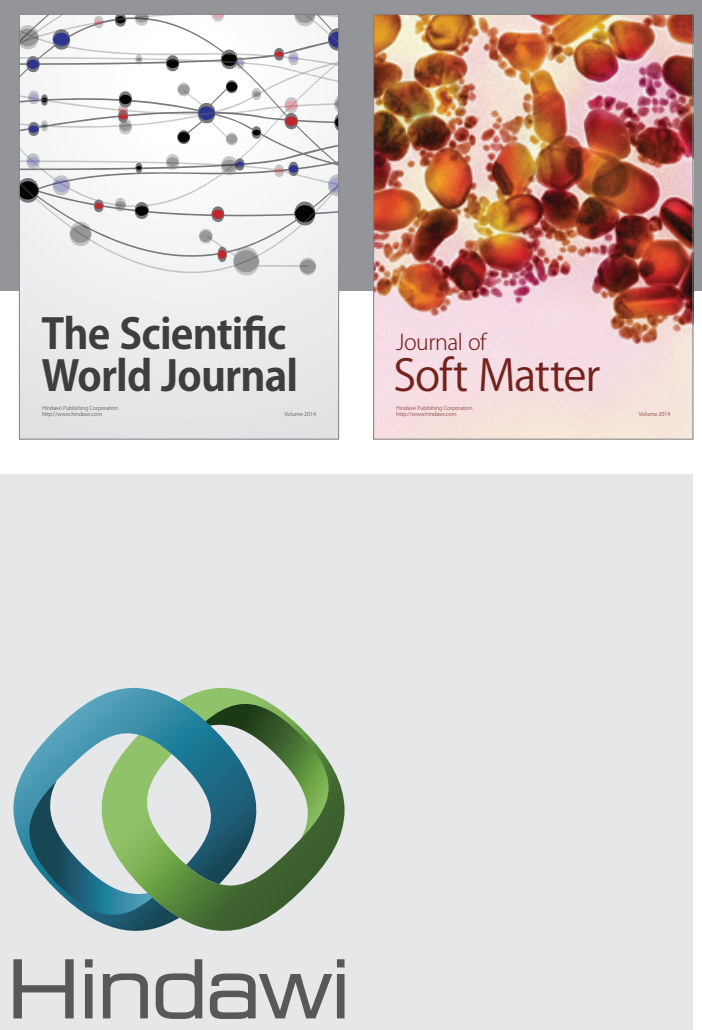

Submit your manuscripts at

http://www.hindawi.com

nternational Journal of

Statistical Mechanics
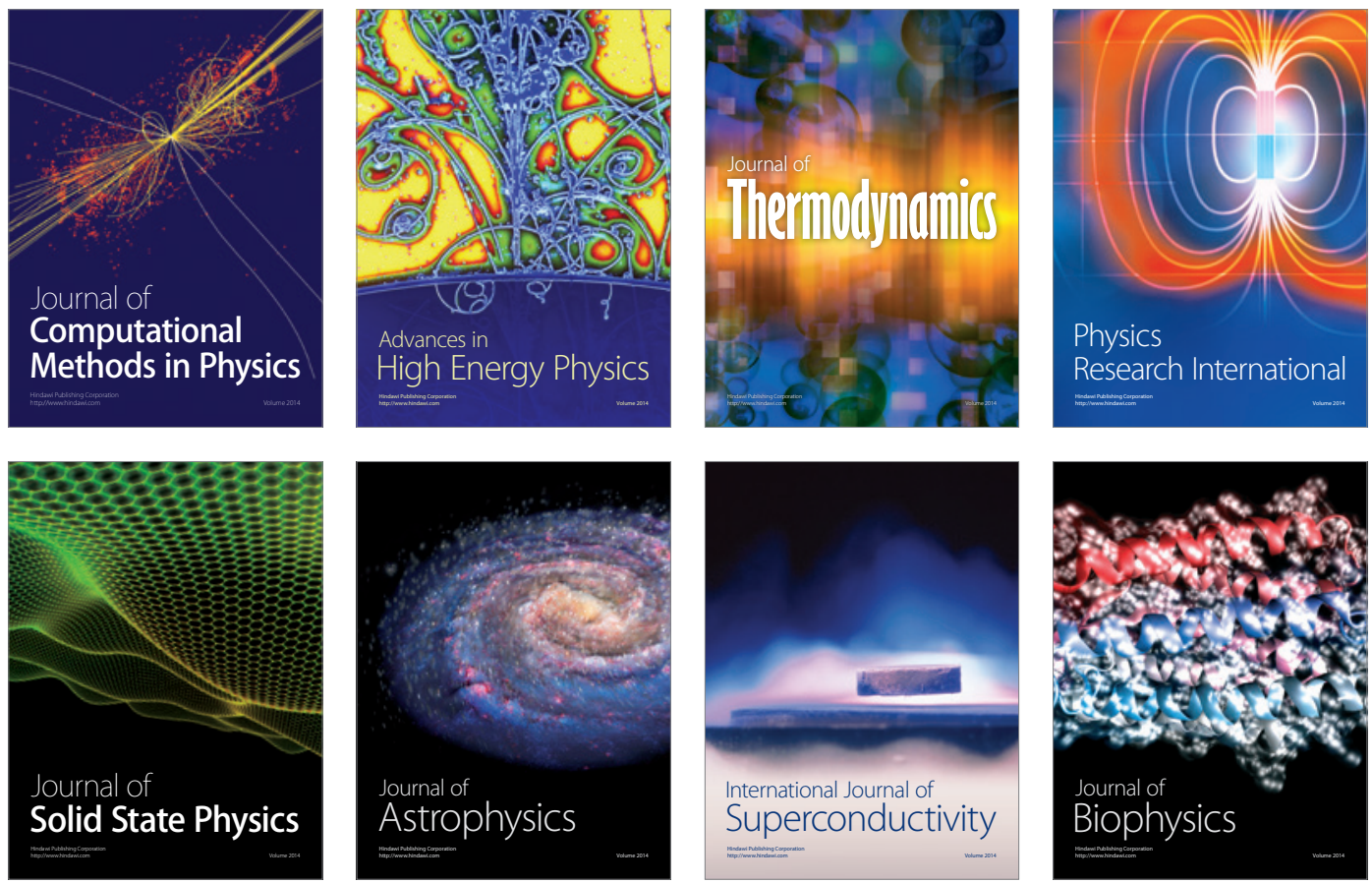
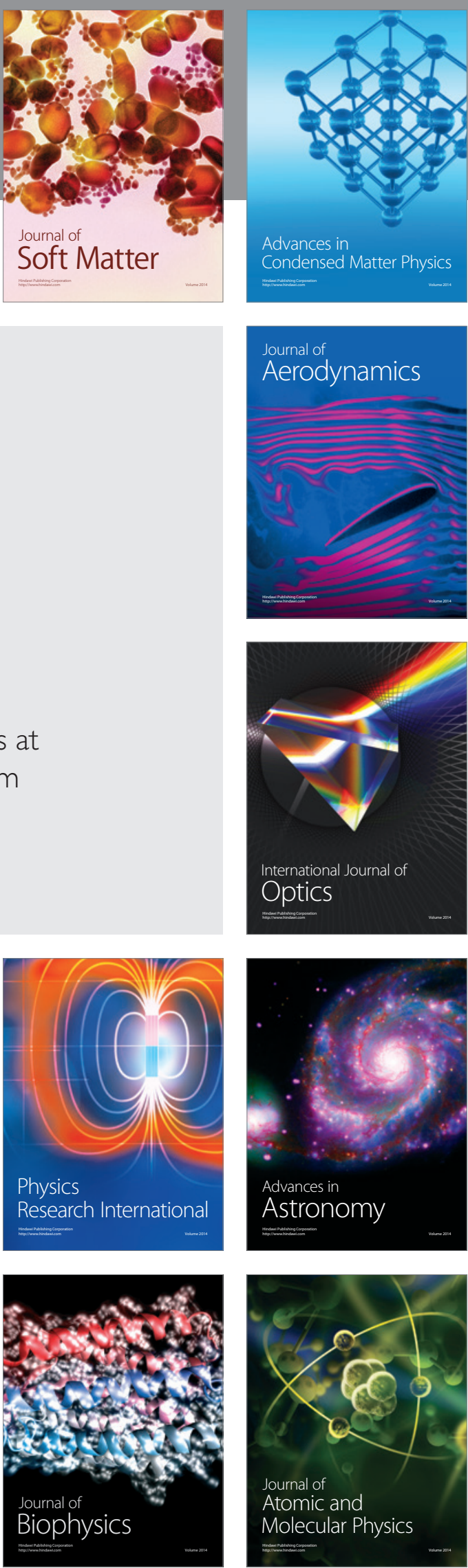